\title{
Optimization of Income Parameters of Songket Craftsmen on Koperasi Songket Palembang
}

\author{
Neneng Miskiyah ${ }^{1 *}$, Purwati Purwati ${ }^{1}$, Yulia Pebrianti ${ }^{1}$, Keti Purnamasari ${ }^{1}$, \\ Nyimas Miftahul Jannah ${ }^{1}$, Rina Dwi Aprianti ${ }^{1}$, Tiara Tiara ${ }^{1}$ \\ ${ }^{1}$ Department of Business Administration, Sriwijaya State Polytechnic, Palembang \\ *Corresponding Author: Email: nenengmiskiyah@polsri.ac.id
}

\begin{abstract}
The purpose of a business is to obtain income that can be used to meet the needs of life and business survival. To obtain optimal income, it is necessary to know the optimum point of business capital, business experience, partnerships, and allocation of working hours. In this study, the number of samples was 30 craftsmen who became members of Kopsop. Data is collected through instruments based on predetermined variables for approximately 2 months by going directly to the craftsmen. The method used is Response Surface Methodology (RSM). The experimental design used is the Central Composite Design for order 2, where the quantitative form of the relationship between the desired response and the independent variable is in the quadratic order model. The results showed that the optimum condition of income for Songket craftsmen was Rp 3.561.590, - with a business capital of Rp 3.000.000, 6 years of business experience, 9 hours/day allocation of working hours, and 4 years of partnership.
\end{abstract}

Keywords: Craftsman Income, Optimizing Parameters, Response Surface Methodology

\section{INTRODUCTION}

The COVID-19 pandemic has had an impact on the economic viability of business households and worker households. According to [1] revealed that Covid-19 had a socio-economic impact on household income which affected household consumption and savings which fell significantly. This condition was exacerbated by a decline in public demand, changes in public consumption behaviour, and a general slowdown in economic activity. The same thing was also stated by [2] that the pandemic caused increased unemployment, decreased household income, and decreased consumption of goods and services.

The impact of the Covid-19 pandemic has also affected the Palembang Songket craft business. The decline in the income of craftsmen due to reduced public demand for Songket cloth. In an effort to increase the income of craftsmen, through the business group of Koperasi Songket Palembang (Kopsop) which is a means to help Songket craftsmen market their work. Income with maximum profit is not the only main goal of the Koperasi Songket Palembang, but rather to business continuity and development in the Palembang Songket weaving business, while the income of the craftsmen itself is received from various supporting factors including business capital, business experience, allocation of working hours, and partnerships. Factors that affect the income of craftsmen need to be calculated in order to obtain optimum values so that craftsmen can optimize their income from the results of Songket weaving.

Limited capital makes it difficult for businessmen to develop their products, therefore capital is used as the basis for conducting a business [3][4]. Another factor that affects the income of craftsmen is business experience. Findings [5][6] suggest that the longer a person is in their job, the more experience they have so that they are more skilled. However, in contrast to the findings [7] stated that business experience had no significant effect on the income of seaweed farmers. Songket craftsmen are mostly done by women, because this work can be done from home. The woman's dual role is as a Songket craftsman as well as a housewife who takes care of her children and husband. The existence of a dual role requires women craftsmen to be able to allocate work time between work as a Songket craftsman, and work taking care of the household. Basically the income of craftsmen depends on the time or working hours used. The more time he spends working, it is expected that the more income he will receive. Working hours have a unidirectional relationship with income, meaning that the greater the working hours, the greater the income [6][8]. However, different research results found by [3] that working hours have no effect on 
the income of traders in the Landungsari market.

The length of time for Songket craftsmen who are members of the Koperasi Songket Palembang varies, an average of more than 4 years. Basically partnership is a mutually beneficial activity with various forms of cooperation in dealing with and strengthening each other. In this regard, business partnerships contain several main elements which are business cooperation with the principles of mutual benefit, mutual strengthening and mutual need. Findings [9] state that partnerships have a significant effect on income. The partnership has a positive influence on the income of sugarcane farming, so that sugarcane farmers who participate in the partnership earn higher incomes than nonpartner sugarcane farmers

This study determines and analyzes the optimization of the income parameters of craftsmen from the variables of business capital, business experience, allocation of working hours, and partnerships using Response Surface Methodology (RSM). This article is organized into 5 parts, namely (1) introduction; (2) literature review; (3) research methods; (4) results and discussion; and the final section (5) conclusion.

\section{LITERATURE REVIEW}

\subsection{Income Theory}

The purpose of a business is to obtain income that can be used to meet the needs of life and business survival. Income is all money or other material results achieved from the use of wealth or services received by a person or household during a certain period of time in an economic activity [10][11]. According to [12] income which shows the amount of money received by households within a certain time, can be in the form of wages (labor receipts), rent, interest, dividends, transfer payments (wealth income), social benefits or unemployment insurance (revenues from the government).

\subsection{Factors Affecting Income}

\subsubsection{Business Capital}

Capital is a factor of production in a business process. By allocating and utilizing capital properly and efficiently, it facilitates the product process. Business capital can be in the form of money, goods, and services used to produce a product either directly or indirectly. Capital comes from own capital and loan capital. But in reality the capital itself is not sufficient so that the steps taken by business actors are to seek loan capital. Business capital has a positive and significant effect on household income, because capital is one of the inputs (factors of production) in determining the level of income to be obtained [13][14][15].

\subsubsection{Business Experience}

Business experience is the length of time a person has lived in a particular job. The longer the business is run, the more experience will be gained [16]. One's business experience can be an advantage and can innovate in every job done. Within a certain period of time, businessmen can gain knowledge and skills at work. Findings [17] that work experience has a significant influence on the income of workers in the public or private sector in both urban and rural areas.

\subsubsection{Allocation of Working Hours}

In general, working hours are the total working time of all jobs during the past week. It is assumed that the more hours of work used, the more productive the work done. Workers whose working hours are low affect the income received, the higher the working hours, the greater the income received [3]. The same thing was also found [6] that working hours affect the income of ornamental fish traders. However, the results of research conducted [14][18] actually did not have an effect on income.

\subsubsection{Partnership}

In Undang-Undang Nomor 9 Tahun 1995 concerning Small Businesses (Pasal 1) and Peraturan Pemerintah Nomor 44 Tahun 1997 concerning Partnerships (Pasal 1), it is explained that partnership is defined as cooperation between Small and Medium Enterprises and or Large Enterprises by taking into account the principle of mutual need, mutually reinforcing, and mutually beneficial. Business people are in an equal position, even though they are economically equal partners, they work on different business scales [19].

According to [20] explained that a partnership is a business strategy carried out by two or more parties within a certain period of time to obtain mutual benefits with the principle of mutual need and raising. Meanwhile, according to [21], partnership is an attitude of running a business with the characteristics of long-term relationships, highlevel cooperation, mutual trust between the two parties to achieve common business goals. There are six benefits obtained by implementing the partnership pattern, namely (1) the achievement of high productivity; (2) achieving efficiency; (3) quality, quantity and continuity assurance; (4) risk 
management, (5) social benefits; and (6) economic resilience [19].

\section{RESEARCH METHODS}

The research was conducted on Palembang Songket craftsmen who are members of the Koperasi Songket Palembang (Kopsop) located in Ki Gede Ing Suro, Ilir Barat II, Palembang. The population in this study were Songket craftsmen who were members of Kopsop as many as 30 people. The sampling technique used is a saturated sample, where all the population is used as a sample of 30 craftsmen. Quantitative analysis to identify the effect of the independent variable on the dependent variable using the Response Surface Methodology (RSM). The independent variables are business capital, business experience, allocation of working hours, and partnerships, while the dependent variable is the income of Songket craftsmen.

In this study using the Central Composite Design (CCD) to minimize the amount of research data. Level and coding using equation [22].

$$
x_{i 1}=\frac{\xi_{i 1}-\left[\max \left(\xi_{i 1}\right)+\min \left(\xi_{i 1}\right)\right] / 2}{\left[\max \left(\xi_{i 1}\right)-\min \left(\xi_{i 1}\right)\right] / 2}=
$$

The independent variables in this study were coded using equation 1 by considering the research data.

Table 1 Independent Variables in Experiment

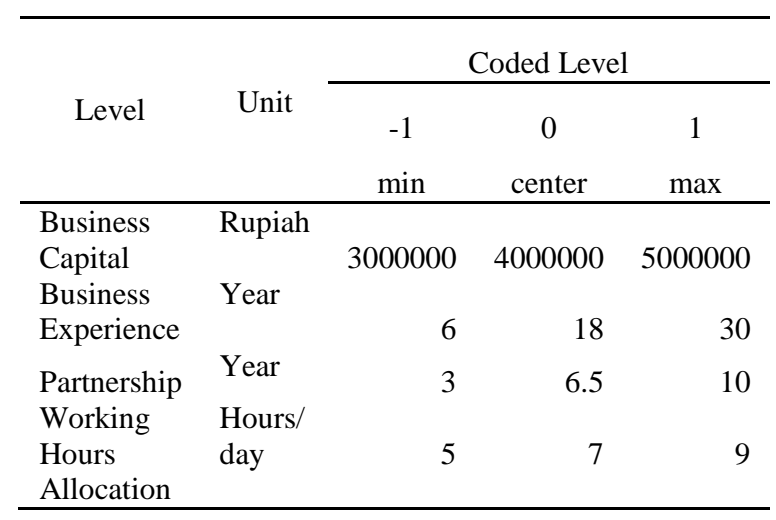

Source: data processing results, 2021

Response Surface Methodology is a collection of statistical and mathematical techniques used for modeling and analyzing problems where the desired response is influenced by variables and aims to optimize the response [22].

Table 2 Research Experiment Design and Experimental Results

\begin{tabular}{rrrrrrrr}
\multicolumn{1}{c}{ Std } & \multicolumn{1}{c}{ Run } & \multicolumn{1}{c}{ X1 } & X2 & X3 & X4 & Y \\
\hline \multirow{5}{*}{ Factorial } & 1 & 14 & 3000000 & 6 & 3 & 5 & 4250000 \\
& 2 & 16 & 5000000 & 6 & 3 & 5 & 4500000 \\
& 3 & 27 & 3000000 & 30 & 3 & 5 & 4250000 \\
& 4 & 26 & 5000000 & 30 & 3 & 5 & 5800000 \\
& 5 & 18 & 3000000 & 6 & 10 & 5 & 4250000 \\
& 6 & 30 & 5000000 & 6 & 10 & 5 & 4500000 \\
& 7 & 21 & 3000000 & 30 & 10 & 5 & 4250000 \\
& 8 & 29 & 5000000 & 30 & 10 & 5 & 5400000 \\
& 10 & 24 & 3000000 & 6 & 3 & 9 & 3250000 \\
& 11 & 19 & 5000000 & 6 & 3 & 9 & 4900000 \\
& 12 & 6 & 3000000 & 30 & 3 & 9 & 4250000 \\
& 13 & 11 & 30000000 & 30 & 3 & 9 & 5800000 \\
& 14 & 17 & 5000000 & 6 & 10 & 9 & 3750000 \\
& 15 & 7 & 3000000 & 30 & 10 & 9 & 4500000 \\
& 16 & 25 & 5000000 & 30 & 10 & 9 & 4750000 \\
& 16 & 1 & 3000000 & 18 & 6.5 & 7 & 4250000 \\
& 17 & 22 & 5000000 & 18 & 6.5 & 7 & 4900000 \\
& 18 & 20 & 4000000 & 6 & 6.5 & 7 & 4750000
\end{tabular}




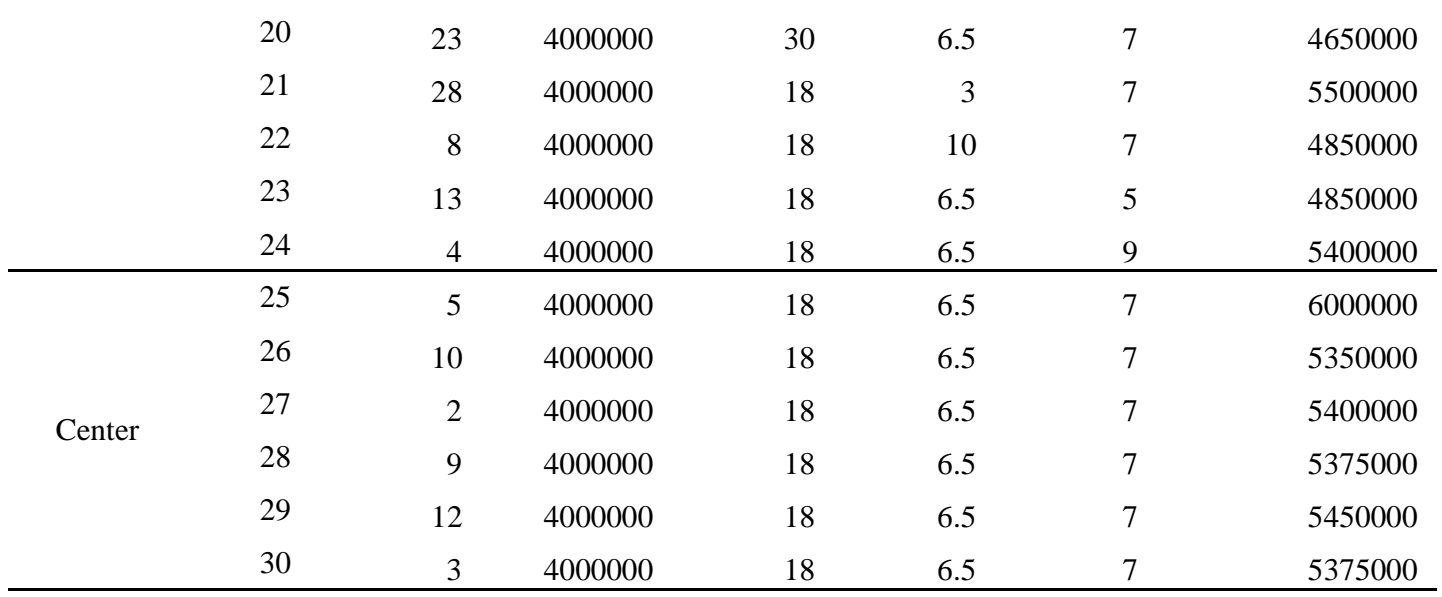

Source: data processing results, 2021

To find out and analyze the relationship between the income parameters of Songket craftsmen, the Response Surface Methodology approach is used, where the quantitative form of the relationship between the desired response and the independent variable is in a quadratic order model.

\section{RESULTS AND DISCUSSION}

Almost all of Palembang's Songket woven businessmen have difficulty in selling, thereby reducing supply and even having to temporarily stop the supply of weaving children or craftsmen so as not to lose money. This condition is done to avoid stock accumulation. The Koperasi Songket Palembang still receives a very limited number of weaving products from craftsmen, because it is to help craftsmen who only rely on income from these businesses.
Variables of business capital, business experience, allocation of working hours, and partnerships are factors that affect the income of craftsmen. To optimize the income of craftsmen, it is necessary to calculate and analyze in order to obtain the optimum value of each independent variable.

From the results of data processing, it is found that the first-order model equation for the model and Lack of Fit is significant, so that the model is invalid and cannot be used. Furthermore, data processing is carried out by making second-order model equations. The second-order model was obtained by the central composite design method [24]. The second-order model is obtained from the use of the RSM method as follows:

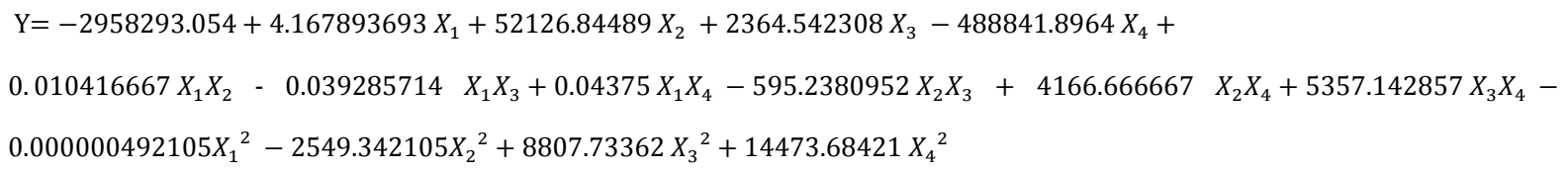

Table 3 ANOVA for Response Surface Quadratic Model

\begin{tabular}{|c|c|c|c|c|c|}
\hline Source & Sum of Squares & df & Mean Squares & F Value & p-value \\
\hline Model & $1.00927 \mathrm{E}+13$ & 14 & 7.20904E+11 & 4.947277 & significant \\
\hline A-Business Capital & $3.96681 \mathrm{E}+12$ & 1 & $3.96681 \mathrm{E}+12$ & 27.2226 & 0.0001 \\
\hline B-Business Experience & $1.93389 \mathrm{E}+12$ & 1 & $1.93389 \mathrm{E}+12$ & 13,27151 & 0.0024 \\
\hline $\begin{array}{l}\text { C-Partnership } \\
\text { D-Allocation of Working }\end{array}$ & 40138888889 & 1 & 40138888889 & 0.275457 & 0.6074 \\
\hline Hours & 1388888888,9 & 1 & 1388888888,9 & 0.000953 & 0.9758 \\
\hline $\mathrm{AB}$ & $2.5 \mathrm{E}+11$ & 1 & $2.5 \mathrm{E}+11$ & 1.71565 & 0.2100 \\
\hline $\mathrm{AC}$ & $3.025 \mathrm{E}+11$ & 1 & $3.025 \mathrm{E}+11$ & 2.075937 & 0.1702 \\
\hline $\mathrm{AD}$ & $1.225 \mathrm{E}+11$ & 1 & $1.225 \mathrm{E}+11$ & 0.840669 & 0.3737 \\
\hline
\end{tabular}




\begin{tabular}{|c|c|c|c|c|c|c|}
\hline $\mathrm{BC}$ & 10000000000 & 1 & 10000000000 & 0.068626 & 0.7969 & \\
\hline $\mathrm{BD}$ & $1.6 \mathrm{E}+11$ & 1 & $1.6 \mathrm{E}+11$ & 1.098016 & 0.3113 & \\
\hline $\mathrm{CD}$ & 22500000000 & 1 & 22500000000 & 0.154409 & 0.6999 & \\
\hline $\mathrm{A}^{\wedge} 2$ & $6.27434 \mathrm{E}+11$ & 1 & $6.27434 \mathrm{E}+11$ & 4.305831 & 0.0556 & \\
\hline $\mathrm{B}^{\wedge} 2$ & $3,49167 \mathrm{E}+11$ & 1 & $3,49167 \mathrm{E}+11$ & 2.396195 & 0.1425 & \\
\hline $\mathrm{C}^{\wedge} 2$ & 30161483254 & 1 & 30161483254 & 0.206986 & 0.6557 & \\
\hline $\mathrm{D}^{\wedge} 2$ & 8684210526 & 1 & 8684210526 & 0.059596 & 0.8104 & \\
\hline Residual & $2.18576 \mathrm{E}+12$ & 15 & $1.45717 \mathrm{E}+11$ & & & \\
\hline Lack of Fit & $1.86993 \mathrm{E}+12$ & 10 & $1.86993 \mathrm{E}+11$ & 2.960306 & 0.1213 & $\begin{array}{l}\text { not } \\
\text { significant }\end{array}$ \\
\hline Pure Error & $3.15833 \mathrm{E}+11$ & 5 & 63166666667 & & & \\
\hline Total Cast & $1.22784 \mathrm{E}+13$ & 29 & & & & \\
\hline
\end{tabular}

Source: data processing results, 2021

From Table 3, the quadratic model shows that the mathematical model is significant while the lack of fit is not significant. This means that the model is valid and can be used to analyze the response surface of the income of Songket craftsmen.

The significance test through ANOVA testing aims to determine whether there is an effect of the various variables tested on the income of Songket craftsmen. If the data obtained from the results of $\mathrm{R}$ Square $\left(\mathrm{R}^{2}\right)$ equal to 0,821984 it clear that a strong relationship between variables occurs business capital, business experience, partnerships, and the allocation of working hours. The value of $\mathrm{R}^{2}$ of 0,822 means that the influence of venture capital, business experience, the allocation of working hours, and the partnership of $82,2 \%$, while $17,8 \%$ are influenced by other variables outside the study variables.

From the equation of the second order model, the coefficient of each variable is converted into a matrix form. The formation of the matrix and the determination of the optimum point is obtained by means of multiplication and the inverse of the matrix [22]. In this study, the optimum condition with the limit value of business capital, business experience, partnership, and allocation of working hours is "in the range", while the output $(\mathrm{Y})$ which is the income of craftsmen is set to a minimum. The results of determining the optimum point are shown in Table 4 below.

Table 4 Optimal Conditions of Income Parameters for Songket Craftsmen

\begin{tabular}{cccccccc} 
No. & $\begin{array}{c}\text { Business } \\
\text { Capital }\end{array}$ & $\begin{array}{c}\text { Business } \\
\text { Experience }\end{array}$ & $\begin{array}{c}\text { Allocation of } \\
\text { Working Hours }\end{array}$ & Partnership & Income (Y) & Desirability & \\
\hline 1 & $\mathbf{3 0 0 0 0 0 0 . 2 4}$ & $\mathbf{6 . 0 0}$ & $\mathbf{9 . 0 0}$ & $\mathbf{4 . 0 1}$ & $\mathbf{R p ~ 3 . 5 6 1 . 5 9 0}$ & $\mathbf{0 . 8 8 7}$ & Selected
\end{tabular}

Source: data processing results, 2021

From Table 4, it is found that the optimum point of the business capital factor is Rp. 3,000,000.24, the optimum point of the business experience factor is 6 years, the optimum point of the working hours allocation factor is 9 hours/day, and the optimum point of the partnership factor is 4 year with the optimal income of craftsmen of Rp 3.561.590,-.

The business capital issued by the craftsmen ranges from $\mathrm{Rp}$ 3.000.000 to $\mathrm{Rp}$. 5.000.000, there are $30 \%$ of the craftsmen who have a business capital of $\mathrm{Rp} 3.000 .000$. The optimum point of the business capital factor is Rp 3.000.000. In general, business capital is all things (money or other forms) that can be used to run a business. Based on the source of origin, business capital consists of internal capital originating from the business owner himself and external capital originating from loans/debts. From the field survey, all craftsmen only utilize internal capital. The reason for not wanting to get loan capital was because of the craftsman's ignorance of the procedure, and the absence of collateral. Capital is one of the inputs (factors of production) in determining the level of income to be obtained. In research [13][14] explained that business capital has a positive and significant effect on household income. The same thing was also found by [23] that capital has an effect on increasing the income of teak furniture craftsmen and capital. 
Experience in managing a business has an effect on income. Business experience is obtained by craftsmen when they are directly involved in Songket weaving activities. The business experience of songket weaving craftsmen who are members of the Koperasi Songket Palembang Songket is between $6-30$ years. This Songket weaving business experience is obtained based on the parenting pattern of parents who work as craftsmen or from the experience of people who are in the closest environment. By using Response Surface Methodology, the optimum point for business experience is 6 years. The longer the experience in the Songket weaving business, the more the craftsmen have the knowledge and skills in the business they are engaged in. This result is in line with the finding of [17] that work experience has a significant effect on income.

Koperasi Songket Palembang (Kopsop), which was established in 1986, is a member-owned businessentity consisting of typical Palembang fabr ic craftsmen in the form of Songket Fabrics, Tajung Weaving Fabrics, and Jumputan. Kopsop is a forum for Palembang typical woven fabric craftsmen which has 30 members consisting of housewives and young women. During the current Covid-19 pandemic, Kopsop's role is very helpful for craftsmen to keep earning. The relationship between Kopsop and craftsmen is a partnership that shows cooperation in conducting business activities which is a business strategy with the aim of developing a business based on the principles of mutual need, mutual strengthening, and mutual benefit. This principle is what keeps Kopsop standing to this day. The length of time the craftsmen join Kopsop is between $3-10$ years. From the calculation results, the optimum point of partnership is 4 years, meaning that with a period of 4 years joining Kopsop has reached the optimum point to generate optimal income for craftsmen. Research [25] suggests that partnerships have an effect on the income of dairy farmers. However, it was found that [26] the partnership of PT Indofood Fritolay Makmur did not have a positive impact on the income of potato farming in Sembalun District, East Lombok Regency.

The allocation of working hours for craftsmen in doing their job of weaving songket ranges from 5 hours to 9 hours per day. The dual role of the craftswoman between taking care of the household and doing her job as a weaver can be done well. Allocation of working hours is one source of increasing income, the more working hours used, the more productive the work done. Each additional time to weave, the more opportunities to increase sales results. The optimum point of the allocation of working hours is 9 hours/day, which means that at this point it contributes to optimizing the income of the craftsmen. Research conducted [27] revealed that working hours affect the income of traders in Selatbaru beach tourism. In contrast to the findings of [28] working hours have no effect on the income of traders, the higher the working hours used by a person in trading does not affect the level of income received.

\section{CONCLUSION}

The significance of test results obtained $\mathrm{R}$ Square $\left(\mathrm{R}^{2}\right)$ equal to 0,821984 , or $82,2 \%$ of the second-order model is explained by variable business capital, business experience, the allocation of working hours, and partnerships, the rest is influenced by other variables outside the study variables.

The optimum point of business capital, business experience, partnership, and allocation of working hours that generate optimal income for craftsmen is $\mathrm{Rp}$ 3.000.000 for business capital, for business experience is 6 years, partnership is 4 years, and the allocation of working hours is 9 hours/day with generate optimal income of Songket craftsmen of Rp 3.561.590,--

\section{ACKNOWLEDGMENTS}

This research was supported by the Sriwijaya State Polytechnic. The author would like to thank Sriwijaya State Polytechnic colleagues who have provided insight and expertise that were very helpful in this research.

\section{REFERENCES}

[1] Martin, Amory, dkk. 2020. Socio-Economic Impacts of COVID-19 on Household Consumption and Poverty. Economics of Disasters and Climate Change 4: 453-479. https://doi.org/10.1007/s41885-020-00070-3.

[2] Celik, Bilal, Ozden, Kemal, and Senol Dane. 2020. The Impact of Covid-19 on The Household Economy and Consumption Preferences: An International Survey. Journal of Global Economics and Business, Vol. 1, No. 2, pp. 91-115.

[3] Prihatminingtyas, Budi. 2019. Pengaruh Modal, Lama Usaha, Jam Kerja dan Lokasi Usaha Terhadap Pendapatan Pedagang di Pasar Landungsari. Jurnal Ilmu Manajemen dan Akuntansi, Vol. 7, No. 2, hal. 147-154.

[4] Arianty, Nel. 2017. Analisis Usaha Industri Rumah Tangga dalam Meningkatkan 
Pendapatan Keluarga. Prosiding Seminar Hilirisasi Penelitian untuk Kesejahteraan Masyarakat, Lembaga Penelitian Universitas Negeri Medan.

[5] Rani. 2019. Pengaruh Modal dan Lama Usaha Terhadap Pendapatan Pedagang di Pasar Tradisional Pasar Minggu. Widya Cipta (Jurnal Sekretaris dan Manajemen), Vol. 3, No. 1, hal. 143-148.

[6] Rusmusi IMP, dan Afrah Nabila Maghfira. 2018. Pengaruh Modal, Jam Kerja dan Lama Usaha Terhadap Pendapatan Pedagang di Pasar Ikan Hias Mina Restu Purwokerto Utara. Jurnal Ekonomi, Bisnis, dan Akuntansi (JEBA), Vol. 20, No. 04, hal. 1-9.

[7] Ni Kadek Nita Antari dan Made Suyana Utama. 2019. Analisis Faktor-Faktor yang Mempengaruhi Pendapatan Petani Rumput Laut. E-Jurnal Ekonomi Pembangunan Universitas Udayana, Vol. 8, No. 1, hal. 179210.

[8] Khaswarina, Shorea. 2017. Faktor Dominan yang Mempengaruhi Ekonomi Rumah Tangga Petani Karet di Desa Koto Damai Kabupaten Kampar. Sosiohumaniora, Vol. 19, No. 3, hal. 199-205.

[9] Naim, Syaifun, Lutfi Aris Sasongko, dan Eka Dewi Nurjayanti. 2015. Pengaruh Kemitraan Terhadap Pendapatan Usaha Tani Tebu. Mediagro, Vol. 11, No. 1, hal. 47-59.

[10] Firdausa, Rosetyadi Artistyan, dan Fitrie Arianti. 2013. Pengaruh Modal Awal, Lama Usaha dan Jam Kerja Terhadap Pendapatan Pedagang Kios di Pasar Bintaro Demak. Diponegoro Journal of Economivs, Vol. 2, No. 1, hal. 1-6.

[11] Sukirno, Sadono. 2006. Teori Pengantar Mikro Ekonomi. Jakarta: Rajagrafindo Persada.

[12] Samuelson, Paul A, dan William D Nordhaus. 2004. Ilmu Makro Ekonomi. Jakarta: PT Media Edukasi.

[13] Nyoman Diatmika, Djinar Setiawina, dan Ketut Djayastra. 2016. Analisis Faktor-Faktor yang Mempengaruhi Pendapatan Petani Anggrek di Kota Denpasar. E-Jurnal Ekonomi dan Bisnis Universitas Udayana, Vol. 5, No. 10, hal. 3175-3202.

[14] Yustie, Renta, dan Diah Ayu Retnowati. 2020. Determine The Effect of Capital, Labor, and Working Hours on Merchant Income in
Surabaya Puncak Permai Modern Market in 2019. Jurnal Ilmu Ekonomi Terapan, Vol. 5, No. 1, hal. 1-12.

[15] Kurniati, Annisa. 2013. Pengaruh Modal Kerja Terhadap Pendapatan Pengrajin Industri Kecil Tempe di Desa Sambak Kecamatan Kajoran Kabupaten Magelang. Oikonomia, Vol. 2, No. 3, hal. 163-168.

[16] Wijayanti, Rena Feri. 2010. Connect Surfing New Wave Marketing. Jakarta: Gramedia Pustaka Utama.

[17] Taufiqurahman, Endang. 2012. Pengaruh Pendidikan dan Pengalaman pada Pendapatan Rumah Tangga di Indonesia. Ekuitas: Jurnal Ekonomi dan Keuangan, Vol. 17, No. 4, hal. 451-467.

[18] Ni Kadek Arifini dan Made Dwi Setyadhi Mustika. 2013. Analisis Pendapatan Pengrajin Perak di Desa Kamasan Kabupaten Klungkung. E-Jurnal Ekonomi Pembangunan Universitas Udayana, Vol. 2, No. 6, hal. 294305.

[19] Noorjaya, Tika. 2001. Business Linkage: Enhancing Access of SME to Financing Institutions. ADB SME Development. http://www.ekonomirakyat.org

[20] Hafsah, Mohammad Jafar. 2000. Kemitraan Usaha. Jakarta: Sinar Harapan.

[21] Linton L. 1995. Parthnership Modal Ventura. Jakarta: PT IBEC.

[22] Myers, Raymond, Douglas C. Montgomery, dan Christine M. Anderson. 2009. Response Surface Methodology: Process and Product Optimization Using Designed Experiments (Third Edition). USA: John Wiley \& Sons, Inc.

[23] Nasikh. 2009. Model Optimalisasi Faktor Produksi Usaha Industri Kecil Mebel Kayu Jati di Pasuruan Jawa Timur. Jurnal Manajemen dan Kewirausahaan, Vol. 11, No. 1, hal. 8593.

[24] Bettoncil, B.W.M.E, del Castilo, and J.P.C Kleijnen. 2009. Statistical Testing of Optimality Conditions in Multiresponse Simulation-Based Optimization. European Journal of Operation Research, Vol. 199, No. 2, pp. 448-458.

[25] Hardiyanti, Endra, Dwi Susilowati, dan Zainal Arifin. 2019. Pengaruh Kemitraan Usaha Koperasi Susu Terhadap Jumlah Pendapatan 
Peternak Sapi Perah. Jurnal Ilmu Ekonomi (JIE), Vol. 4, No. 3, hal. 547-555.

[26] Sopiana, Heni, dan Rini Endang Prasetyowati. 2020. Dampak Kemitraan PT Indofood Fritolay Makmur (IFM) Terhadap Pendapatan Petani Kentang di Kecamatan Sembalun Kabupaten Lombok Timur. Jurnal Ilmiah Rinjani (JIR): Media Informasi Ilmiah Universitas Gunung Rinjani, Vol. 8, No. 1, hal. 54-65.
[27] Sari, Novia, dan Sandi Andika. 2020. Pengaruh Modal, Lokasi dan Jam Kerja Terhadap Tingkat Pendapatan Pedagang di Wisata Pantai Selatbaru Kecamatan Bantan dalam Perspektif Ekonomi Islam. Bertuah: Jurnal Syariah dan Ekonomi Islam, Vol. 1, No. 2, hal. 16-31.

[28] Husaini, dan Ayu Fadhlani. 2017. Pengaruh Modal Kerja, Lama Usaha, Jam Kerja, dan Lokasi Usaha Terhadap Pendapatan Monza di Pasar Simalingkar Medan. Jurnal Visioner \& Strategis, Vol. 6, No. 2, hal. 111-126. 